\title{
Meroterpenoids from Neosetophoma sp.: A Dioxa[4.3.3]propellane Ring System, Potent Cytotoxicity, and Prolific Expression
}

Tamam El-Elimat, $^{\dagger}$ Huzefa A. Raja, ${ }^{\ddagger}$ Sloan Ayers, ${ }^{\ddagger}$ Steven J. Kurina, ${ }^{\S}$ Joanna E. Burdette, ${ }^{\S}$ Zachary Mattes, "Robert Sabatelle, ${ }^{\perp}$ Jeffrey W. Bacon," Aaron H. Colby, ${ }^{\perp}$ Mark W. Grinstaff, ${ }^{\perp, \| \odot}$

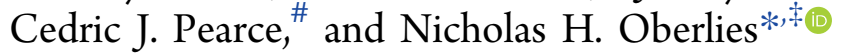

${ }^{\dagger}$ Department of Medicinal Chemistry and Pharmacognosy, Faculty of Pharmacy, Jordan University of Science and Technology, Irbid 22110, Jordan

${ }^{\ddagger}$ Department of Chemistry and Biochemistry, University of North Carolina at Greensboro, Greensboro, North Carolina 27402, United States

${ }^{\S}$ Department of Medicinal Chemistry and Pharmacognosy, University of Illinois at Chicago, Chicago, Illinois 60612, United States

"Department of Chemistry, Boston University, Boston, Massachusetts 02215, United States

${ }^{\perp}$ Department of Biomedical Engineering, Boston University, Boston, Massachusetts 02215, United States

${ }^{\#}$ Mycosynthetix, Inc., Hillsborough, North Carolina 27278, United States

\section{Supporting Information}

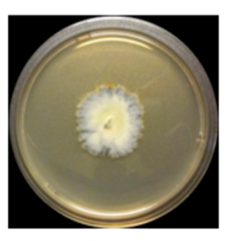

Neosetophoma sp.

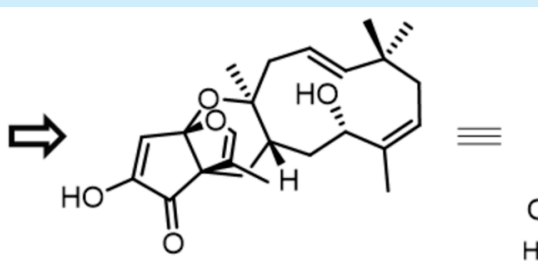

1

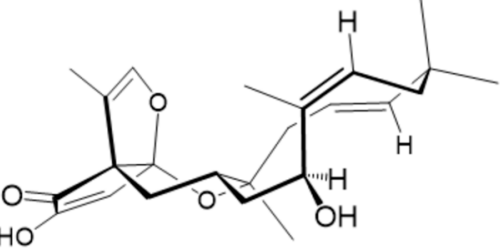

$\mathrm{HO}^{-}$

ABSTRACT: Six fungal metabolites, of which five were new, including one (1) with a dioxa[4.3.3] propellane ring system, were discovered, identified, and structurally elucidated from Neosetophoma sp. (strain MSX50044); these compounds are similar to the bis-tropolone, eupenifeldin. Three of the meroterpenoids are potent cytotoxic agents against breast, ovarian, mesothelioma, and lung cancer cells with nanomolar $\mathrm{IC}_{50}$ values while not inducing mitochondrial toxicity at $12.5 \mu \mathrm{M}$.

M eroterpenoids, compounds originating from hybrid terpenoid and polyketide biosynthesis, are significant due to their wide-range of biological activities, the unusual enzyme reactions that afford the connectivity of their structures, and their unique ring systems. ${ }^{1,2}$ Neosetophoma (Phaeosphaeriaceae) is a recently described ascomycete genus in the kingdom fungi, and a very limited set of secondary metabolites have been reported from Neosetophoma samarorum. ${ }^{3}$ Herein, we report five new and one known meroterpenoids (1-6; Figure 1), including the discovery of a novel dioxa[4.3.3] propellane metabolite (1) that incorporates a 3-methyl-2,3-dihydrofuran bridge into a 5,6 tricyclic 2hydroxycyclopent-2-en-1-one/tetrahydropyran ring system, from an undescribed Neosetophoma sp. [strain MSX50044; see the Supporting Information (SI)], supporting the hypothesis that new fungal species biosynthesize novel chemical scaffolds. ${ }^{4}$ Specifically, we describe the isolation and structural elucidation of the meroterpenoids, mitochondrialbased toxicity, and cytotoxicity against breast, ovarian, mesothelioma, and lung cancer cells.

Solid-phase cultures of Neosetophoma sp. were grown on rice (see the SI). The organic extract $\left[\mathrm{CHCl}_{3}-\mathrm{MeOH}(1: 1)\right]$ of the fermentation culture exhibited potent cytotoxic activity against $\mathrm{H} 460$ (lung) cancer cells when tested at $2 \mu \mathrm{g} / \mathrm{mL}$. After dereplication studies, ${ }^{5}$ the extract was purified using normal-phase flash chromatography to afford eight fractions. Fractions six and seven showed potent activities against $\mathrm{H} 460$ cells with $79 \%$ and $97 \%$ cell growth inhibition, respectively, when tested at $2 \mu \mathrm{g} / \mathrm{mL}$, and were subsequently chromatographed on a $\mathrm{C}_{18}$ preparative HPLC column to yield compounds neosetophomone A (1, $3.94 \mathrm{mg})$, neosetophomone B (2, $56.38 \mathrm{mg})$, eupenifeldin (3, $296.95 \mathrm{mg})$, dehydroxyeupenifeldin $(4,6.54 \mathrm{mg})$, noreupenifeldin B (5, $10.75 \mathrm{mg}$ ), and 22-hydroxyramiferin $(6,4.96 \mathrm{mg}$ ) (Figure 1 and Figure S1). The purity of $\mathbf{1 - 6}$ was $>97 \%$ as assessed by UPLC (Figure S2).

HRESIMS and 1D/2D NMR data identified compound 3 as the bis-tropolone sesquiterpenoid, eupenifeldin ${ }^{6}$ (Table S1 and Figures S3-S8). The absolute configuration of $\mathbf{3}$ was confirmed as $8 R, 9 S, 10 S, 12 S, 13 S$ by vibrational circular

Received: December 3, 2018

Published: January 8, 2019 


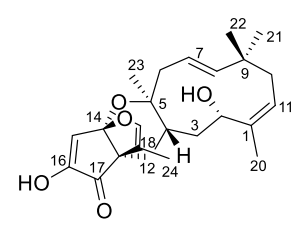

1

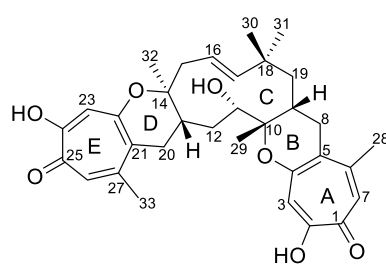

3

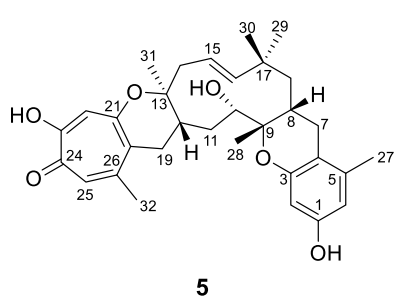

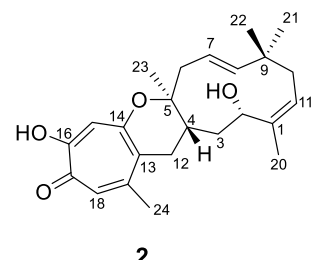
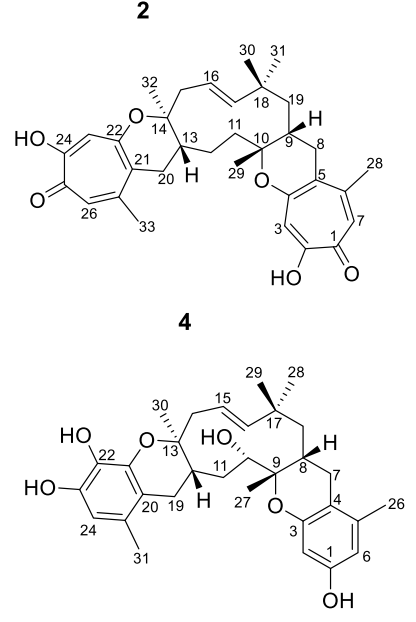

6
Figure 1. Meroterpenoids $(\mathbf{1}-\mathbf{6})$ isolated from a Neosetophoma sp.

dichroism (VCD) (Figure S9), supportive of a recent report by electronic circular dichroism (ECD).

Compound 1 (3.94 mg) was isolated as a white amorphous powder. The molecular formula was deduced as $\mathrm{C}_{24} \mathrm{H}_{32} \mathrm{O}_{5}$ by HRESIMS, indicating an index of hydrogen deficiency of 9 (Figure S3). Comparison of the ${ }^{1} \mathrm{H},{ }^{13} \mathrm{C}$, and edited-HSQC NMR data of $\mathbf{1}$ with that of 3 suggested several intriguing structural differences (Figures S10 and S11). In particular, it appeared that $\mathbf{1}$ had only one dihydro- $2 \mathrm{H}$-pyran ring and lacked both tropolone rings, as evidenced by the absence of the characteristic tropolonic carbonyl resonances (i.e., $\sim \delta_{\mathrm{C}} 172$, Table S1); it also lacked the aromatic methine singlets and the aromatic carbons (Table 1 and Figures S10 and S11). The COSY NMR spectrum of 1 displayed three isolated proton spin systems $\left(\mathrm{H}-2 / \mathrm{H}_{2}-3 / \mathrm{H}-4 / \mathrm{H}_{2}-12, \mathrm{H}_{2}-6 / \mathrm{H}-7 / \mathrm{H}-8\right.$, and $\mathrm{H}_{2}-$ $10 / \mathrm{H}-11)$, which were connected via tertiary and quaternary carbons (C-5 and C-9, respectively), and one nonprotonated vinylic carbon (C-1), constituting the 11-membered sesquiterpene ring (humulene unit $\mathrm{C}$ ), which was fused with the dihydro-2H-pyran at C-4/C-5 (Figures 2 and S12). HMBC correlations from $\mathrm{H}-2$ to $\mathrm{C}-4$ and C-11, from $\mathrm{H}_{2}-3$ to $\mathrm{C}-1, \mathrm{C}-5$, and $\mathrm{C}-12$, from $\mathrm{H}_{2}-6$ to $\mathrm{C}-4, \mathrm{C}-5, \mathrm{C}-8$, and $\mathrm{C}-23$, from $\mathrm{H}_{2}-10$ to $\mathrm{C}-1$ and $\mathrm{C}-8$, and from $\mathrm{H}_{2}-12$ to $\mathrm{C}-3, \mathrm{C}-4$, and $\mathrm{C}-5$ supported this connectivity (Table 1 and Figures 2 and S13). The olefinic protons of the $\Delta^{7,8}$ double bond were in the $E$ configuration $\left(J_{\mathrm{H}-7 / \mathrm{H}-8}=13.2 \mathrm{~Hz}\right)($ Table 1 and Figure S10). A NOSEY correlation was observed between $\mathrm{H}-11$ and $\mathrm{H}_{3}-20$, confirming the $E$-configuration of the $\Delta^{1,11}$ double bond (Figure S14). In comparison with 3, these data (a) established the absence of the dihydro- $2 \mathrm{H}$-pyran-tropolone moieties (i.e., units A and B) in $\mathbf{1}$ and (b) accounted for four degrees of unsaturation, specifically for the humulene ring, two double bonds, and one dihydropyran. We were left to account for five degrees of unsaturation using a methyl, a quaternary carbon, an oxygenated tertiary carbon, a nonprotonated olefinic carbon, two protonated olefinic carbons, an oxygenated olefinic carbon, and an $\alpha, \beta$-unsaturated ketone $\left(\delta_{\mathrm{C}} 199.3\right)$. These data, along
Table 1. ${ }^{1} \mathrm{H}(500 \mathrm{MHz}),{ }^{13} \mathrm{C}(125 \mathrm{MHz})$, and HMBC NMR Data for 1 in $\mathrm{CDCl}_{3}$

\begin{tabular}{|c|c|c|c|}
\hline position & $\delta_{\mathrm{C}}$, type & $\delta_{\mathrm{H}}(J, \mathrm{~Hz})$ & $\mathrm{HMBC}(\mathrm{H} \rightarrow \mathrm{C})$ \\
\hline 1 & 137.1, C & & \\
\hline 2 & $68.5, \mathrm{CH}$ & $4.59(\mathrm{dd}, 8.0,4.6)$ & $20,4,11$ \\
\hline 3 & $38.5, \mathrm{CH}_{2}$ & $\begin{array}{l}1.42 \text { (ddd, 14.9, 8.0, 5.2) } \\
1.94 \text { (ddd, 14.9, 6.3, 4.6) }\end{array}$ & $\begin{array}{l}12,4,2,5,1 \\
12,4,2,5,1\end{array}$ \\
\hline 4 & 31.5, $\mathrm{CH}$ & $1.63(\mathrm{~m})$ & 12 \\
\hline 5 & $81.4, \mathrm{C}$ & & \\
\hline 6 & 49.1, $\mathrm{CH}_{2}$ & $\begin{array}{l}2.38(\mathrm{dd}, 12.6,4.0) \\
2.49(\mathrm{dd}, 12.6,8.0)\end{array}$ & $\begin{array}{l}23,4,5,7,8 \\
23,4,5,7,8\end{array}$ \\
\hline 7 & $121.8, \mathrm{CH}$ & $5.26(\mathrm{dd}, 13.2,4.0)$ & 9 \\
\hline 8 & 144.2, $\mathrm{CH}$ & $5.26(\mathrm{~d}, 13.2)$ & $22,6,7$ \\
\hline 9 & $36.3, \mathrm{C}$ & & \\
\hline 10 & 42.1, $\mathrm{CH}_{2}$ & $\begin{array}{l}1.76(\mathrm{dd}, 13.2,5.7) \\
2.11(\mathrm{dd}, 13.2,12.0)\end{array}$ & $\begin{array}{l}22,9,11,1,8 \\
22,9,11,1\end{array}$ \\
\hline 11 & 125.7, $\mathrm{CH}$ & $5.45(\mathrm{dd}, 12.0,5.7)$ & 20,2 \\
\hline 12 & $27.8, \mathrm{CH}_{2}$ & $\begin{array}{l}1.26(\mathrm{dd}, 13.8,13.2) \\
2.12(\mathrm{dd}, 13.8,3.4)\end{array}$ & $\begin{array}{l}4,3,13,5,18,17 \\
3,13,5,14\end{array}$ \\
\hline 13 & 56.6, C & & \\
\hline 14 & 111.0, C & & \\
\hline 15 & 123.1, $\mathrm{CH}$ & $6.28(\mathrm{~s})$ & 13,17 \\
\hline 16 & 153.2, C & & \\
\hline 17 & 199.3, C & & \\
\hline 18 & 109.9, C & & \\
\hline 19 & $140.3, \mathrm{CH}$ & 6.14 (br. q, 1.7) & $24,13,14$ \\
\hline 20 & $19.4, \mathrm{CH}_{3}$ & $1.72(\mathrm{~s})$ & $2,11,1$ \\
\hline 21 & 28.4, $\mathrm{CH}_{3}$ & $1.08(\mathrm{~s})$ & $22,9,10,8$ \\
\hline 22 & 26.8, $\mathrm{CH}_{3}$ & $1.04(\mathrm{~s})$ & $21,9,10,8$ \\
\hline 23 & 23.2, $\mathrm{CH}_{3}$ & $1.17(\mathrm{~s})$ & $4,6,5,14$ \\
\hline 24 & $8.6, \mathrm{CH}_{3}$ & $1.65(\mathrm{~d}, 1.7)$ & $13,18,19,17$ \\
\hline
\end{tabular}
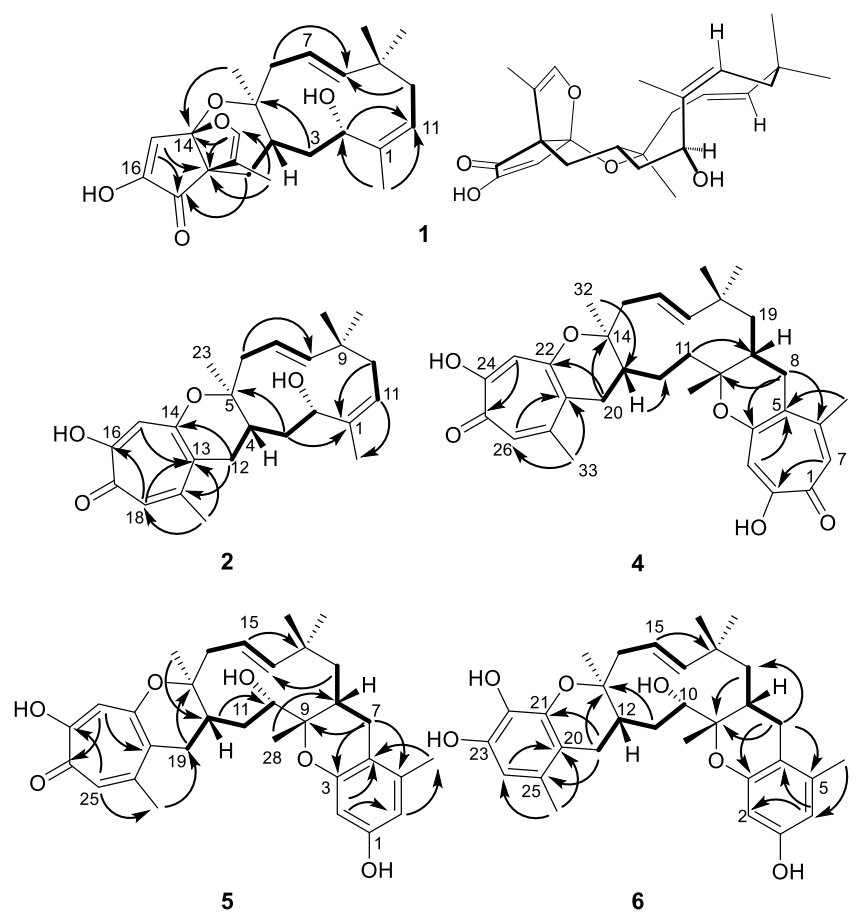

Figure 2. Key COSY and HMBC correlations of 1, 2, and 4-6.

with the fact that there were neither tropolone nor benzene moieties in the structure of $\mathbf{1}$, indicated the existence of two fused rings, which were established by extensive analysis of the HMBC data as 2-hydroxycyclopent-2-en-1-one and 4-methyl- 
2,3-dihydrofuran (Table 1 and Figures 2 and S13). Key HMBC correlations from $\mathrm{H}_{2}-12$ to C-13, C-14, and C-17, from $\mathrm{H}_{3}-23$ to C-14, and from $\mathrm{H}-15$ to $\mathrm{C}-13$ and $\mathrm{C}-17$ documented the fusion of the 2-hydroxycyclopent-2-en-1-one with the dihydropyran at $\mathrm{C}-13 / \mathrm{C}-14$ (Figures 2 and S13). The deshielded nature of $\mathrm{C}-16\left(\delta_{\mathrm{C}} 153.2\right)$ indicated the position of hydroxylation. HMBC correlations from $\mathrm{H}_{3}-24$ to C-13, C17, C-18, and $\mathrm{C}-19$ and from $\mathrm{H}-19$ to $\mathrm{C}-13$ and $\mathrm{C}-14$ established the fusion of the 4-methyl-2,3-dihydrofuran with the dihydropyran and the 2-hydroxycyclopent-2-en-1-one at C13/C-14 to generate a propellane system (Figures 2 and S13). A NOESY correlation between $\mathrm{H}-7$ and $\mathrm{H}_{3}-24$ suggested a synfusion at C-13/C-14 (Figure S14 and S15). This is the first report of a dioxa[4.3.3] propellane system consisting of a 5/5/6 fused ring system, and the name neosetophomone $\mathrm{A}$ was ascribed to 1 . The absolute configuration of 1 was assigned via Mosher's ester method, ${ }^{8}$ establishing the configuration as $(2 S, 4 S, 5 S, 13 S, 14 S)$ (Figure 3). The ${ }^{13} \mathrm{C}$ NMR data of 1 compared favorably with those calculated using ACD laboratories NMR predictor software (Table S2).

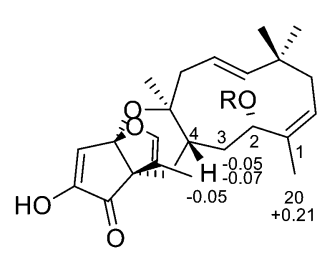

1a: $\mathbf{R}=(S)$-MTPA

$\mathbf{1 b}: \mathrm{R}=(R)-\mathrm{MTPA}$

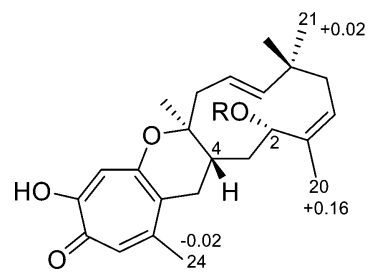

2a: $\mathbf{R}=(S)-$ MTPA

2b: $\mathrm{R}=(R)-\mathrm{MTPA}$
Figure 3. $\Delta \delta_{\mathrm{H}}$ values $\left[\Delta \delta\right.$ (in ppm) $\left.=\delta_{S}-\delta_{R}\right]$ obtained for $(S)$ - and (R)-MTPA esters (A) of neosetophomone A (1) (1) and $\mathbf{1 b}$, respectively) and (B) of neosetophomone B (2) (2a and $2 \mathbf{b}$, respectively) in pyridine- $d_{5}$.

Compound 2 (56.38 mg) was obtained as a white amorphous powder. Its formula was deduced via HRESIMS as $\mathrm{C}_{24} \mathrm{H}_{32} \mathrm{O}_{4}$, which was less than that reported for $\mathbf{1}$ by 16 amu (Figure S3). The NMR data of 2 also indicated structural similarity to 1 and 3 (Table 2 and Figures S16 and S17). In comparison with 3, the NMR data indicated that 2 lacked the dihydropyran/tropolone moiety (i.e., rings A and B), which was consistent with the molecular weight difference between 2 and 3. Also, when comparing the NMR data of $\mathbf{2}$ with that of $\mathbf{1}$, it was evident that both had an identical humulene moiety (ring C). However, although the tropolone $\mathrm{E}$ in $\mathbf{2}$ was intact, that ring underwent oxidative rearrangement in $\mathbf{1}$ as evidenced by a 16 amu difference between 1 and 2 . As in 1 and 3 , the COSY spectrum of 2 showed three isolated proton spin systems that were connected via three carbons (C-5, C-9 and $\mathrm{C}-1)$ to constitute the 11-membered sesquiterpene ring, which was fused with the dihydro- $2 \mathrm{H}$-pyran at C-4/C-5 (Figures 2 and S18). HMBC correlations from $\mathrm{H}-2$ to $\mathrm{C}-11$ and $\mathrm{C}-20$, from $\mathrm{H}_{2}-3$ to $\mathrm{C}-1$ and C-5, from $\mathrm{H}_{2}-6$ to $\mathrm{C}-8$ and C-23, from $\mathrm{H}_{2}-10$ to $\mathrm{C}-1, \mathrm{C}-8, \mathrm{C}-21, \mathrm{C}-22$, and from $\mathrm{H}_{2}-12$ to $\mathrm{C}-3, \mathrm{C}-5$, and $\mathrm{C}-19$ supported this connectivity (Table 2 and Figures 2 and S19). The olefinic protons of the $\Delta^{7,8}$ double bond were in the $E$-configuration $\left(J_{\mathrm{H}-7 / \mathrm{H}-8}=15.9 \mathrm{~Hz}\right)$ (Table 2 and Figure S16). The trivial name neosetophomone B was assigned to 2 . A NOSEY correlation was observed between $\mathrm{H}-11$ to $\mathrm{H}_{3}-20$ that confirmed the E-configuration of the $\Delta^{1,11}$ double bond (Figures S15 and S20). The structure of 2 was confirmed via single-crystal X-ray diffraction (Figure 4), while its absolute

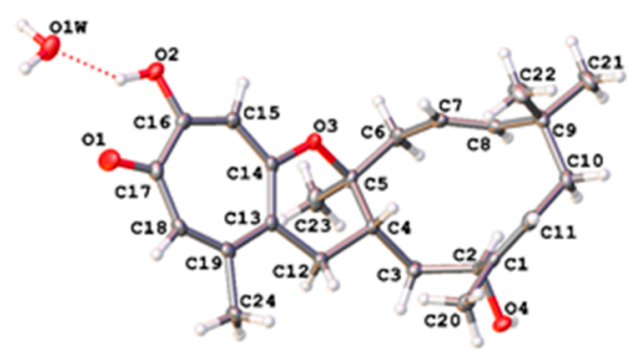

Figure 4. X-ray crystallographic structure of 2.

configuration was assigned via a modified Mosher's ester method, ${ }^{8}$ establishing the configuration as $(2 S, 4 S, 5 S, 13 S, 14 S)$ (Figure 3). Crystallographic data for compd 2 has been deposited with the Cambridge Crystallographic Data Centre (CCDC 1873628).

Compound $4(6.54 \mathrm{mg})$ was obtained as a white amorphous powder. Its formula was deduced via HRESIMS as $\mathrm{C}_{33} \mathrm{H}_{40} \mathrm{O}_{6}$ (Figure S3). The HRESIMS and NMR data indicated that $\mathbf{4}$ was a dehydroxy analogue of 3 , as evidenced by both a $16 \mathrm{amu}$ difference in the HRMS data and replacement of the downfield shifted oxygenated proton in $3\left(\delta_{\mathrm{H}} / \delta_{\mathrm{C}} 4.20 / 70.8\right.$, for $\mathrm{H}-11 / \mathrm{C}$ $11)$ by two upfield shifted aliphatic protons $\left(\delta_{\mathrm{H}} / \delta_{\mathrm{C}} 1.58 / 1.95 /\right.$

Table 2. ${ }^{1} \mathrm{H}(500 \mathrm{MHz})$ and ${ }^{13} \mathrm{C}(100 \mathrm{MHz})$ NMR data for 2 in $\mathrm{CDCl}_{3}$

\begin{tabular}{|c|c|c|c|c|c|}
\hline position & $\delta_{\mathrm{C}}$, type & $\delta_{\mathrm{H}}(J, \mathrm{~Hz})$ & position & $\delta_{\mathrm{C}}$, type & $\delta \mathrm{H}(\mathrm{J}, \mathrm{Hz})$ \\
\hline 1 & 138.0, C & & 12 & $34.5, \mathrm{CH}_{2}$ & 2.46 , dd $(17.5,12.5)$ \\
\hline 2 & $67.0, \mathrm{CH}$ & $4.76, \mathrm{dd}(10.1,6.1)$ & & & $2.67, \mathrm{dd}(17.5,5.4)$ \\
\hline \multirow[t]{2}{*}{3} & 36.7, $\mathrm{CH}_{2}$ & 1.42 , ddd $(14.4,10.1,1.1)$ & 13 & 121.5, C & \\
\hline & & $1.89, \mathrm{dt}(14.4,6.1)$ & 14 & $161.3, \mathrm{C}$ & \\
\hline 4 & $33.0, \mathrm{CH}$ & $1.77, \mathrm{~m}$ & 15 & 113.7, $\mathrm{CH}$ & 6.97, s \\
\hline 5 & $81.4, \mathrm{C}$ & & 16 & $163.5, \mathrm{C}$ & \\
\hline \multirow[t]{2}{*}{6} & 44.3, $\mathrm{CH}_{2}$ & $2.32, \mathrm{dd}(15.0,10.0)$ & 17 & $172.4, \mathrm{C}$ & \\
\hline & & 2.67, ddd $(15.0,2.9,1.5)$ & 18 & 124.6, $\mathrm{CH}$ & $7.10, \mathrm{~s}$ \\
\hline 7 & $119.8, \mathrm{CH}$ & 5.07, ddd $(15.9,10.0,2.9)$ & 19 & $150.0, \mathrm{C}$ & \\
\hline 8 & 144.7, $\mathrm{CH}$ & 5.28, dd $(15.9,1.5)$ & 20 & $18.3, \mathrm{CH}_{3}$ & $1.67, \mathrm{~s}$ \\
\hline 9 & $38.6, \mathrm{C}$ & & 21 & 21.6, $\mathrm{CH}_{3}$ & $0.92, \mathrm{~s}$ \\
\hline \multirow[t]{2}{*}{10} & 40.6, $\mathrm{CH}_{2}$ & $1.78, \mathrm{dd}(13.0,7.3)$ & 22 & $30.2, \mathrm{CH}_{3}$ & $1.05, \mathrm{~s}$ \\
\hline & & $2.11, \mathrm{dd}(13.0,9.9)$ & 23 & 19.5, $\mathrm{CH}_{3}$ & $1.16, \mathrm{~s}$ \\
\hline 11 & 127.0, $\mathrm{CH}$ & 5.36, dd $(9.9,7.3)$ & 24 & $27.2, \mathrm{CH}_{3}$ & $2.37, \mathrm{~s}$ \\
\hline
\end{tabular}


31.5, for $\mathrm{H}_{2}-11 / \mathrm{C}-11$ ) (Tables $\mathrm{S} 1,3$, and 4 and Figure $\mathrm{S} 21$ ). These data, along with COSY, HSQC, HMBC, and NOESY data (Figures 2, S15, and S22-S24) confirmed the structure of 4, which was named dehyroxyeupenifeldin.

Table 3. ${ }^{1} \mathrm{H}$ NMR data for $4\left(400 \mathrm{MHz}, \mathrm{CDCl}_{3}\right), 5$ (500 $\left.\mathrm{MHz}, \mathrm{CDCl}_{3}\right)$, and $6\left(500 \mathrm{MHz}, \mathrm{MeOH}-d_{4}\right)$

\begin{tabular}{|c|c|c|c|}
\hline position & $\begin{array}{c}4 \\
\delta_{\mathrm{H}}(J \text { in } \mathrm{Hz})\end{array}$ & $\begin{array}{c}5 \\
\delta_{\mathrm{H}}(J \text { in } \mathrm{Hz})\end{array}$ & $\begin{array}{c}6 \\
\delta_{\mathrm{H}}(J \text { in } \mathrm{Hz})\end{array}$ \\
\hline 2 & & $6.16(d, 1.7)$ & $6.14(\mathrm{~d}, 2.3)$ \\
\hline 3 & $6.92, \mathrm{~s}$ & & \\
\hline 6 & & $6.33(\mathrm{~d}, 1.7)$ & $6.23(\mathrm{~d}, 2.3)$ \\
\hline \multirow[t]{2}{*}{7} & $7.13, \mathrm{~s}$ & $2.28(\mathrm{dd}, 17.2,15.5)$ & $2.29(\mathrm{~d}, 16.0)$ \\
\hline & & $2.67(\mathrm{dd}, 17.2,5.2)$ & $2.72(\mathrm{dd}, 16.0,4.6)$ \\
\hline \multirow[t]{2}{*}{8} & $2.32, \mathrm{~m}$ & $\begin{array}{l}1.73(\mathrm{ddd}, 15.5,5.2 \text {, } \\
4.6)\end{array}$ & $1.84(\mathrm{~d}, 4.6)$ \\
\hline & 2.78, dd $(17.2,5.3)$ & & \\
\hline 9 & $1.83, \mathrm{~m}$ & & \\
\hline 10 & & $4.18(\mathrm{~d}, 11.5)$ & $4.22(\mathrm{~d}, 11.5)$ \\
\hline \multirow[t]{2}{*}{11} & $1.58, \mathrm{~m}$ & $1.53(\mathrm{dd}, 12.6,11.5)$ & $1.50(\mathrm{dd}, 12.6,11.5)$ \\
\hline & $1.95, \mathrm{t}(11.9)$ & $2.22(\mathrm{~m})$ & $2.29(\mathrm{~m})$ \\
\hline 12 & $\begin{array}{l}1.49, \mathrm{~m} \\
2.18, \mathrm{~m}\end{array}$ & $2.17(\mathrm{~m})$ & $2.19(\mathrm{~m})$ \\
\hline 13 & $2.18, \mathrm{~m}$ & & \\
\hline \multirow[t]{2}{*}{14} & & $2.50(\mathrm{dd}, 13.2,10.9)$ & $2.59(\mathrm{dd}, 13.2,12.6)$ \\
\hline & & $2.71(\mathrm{dd}, 13.2,4.6)$ & $2.79(\mathrm{dd}, 13.2,3.4)$ \\
\hline \multirow[t]{2}{*}{15} & $2.53, \mathrm{~m}$ & $\begin{array}{l}5.63(\mathrm{ddd}, 16.0 \\
10.9,4.6)\end{array}$ & $\begin{array}{l}5.76(\mathrm{ddd}, 16.0 \\
12.6,3.4)\end{array}$ \\
\hline & $2.68, \mathrm{~m}$ & & \\
\hline 16 & $\begin{array}{l}\text { 5.66, ddd (15.9, } \\
11.0,4.8)\end{array}$ & $5.80(\mathrm{~d}, 16.0)$ & $5.88(\mathrm{~d}, 16.0)$ \\
\hline 17 & $5.87, \mathrm{~d}(15.9)$ & & \\
\hline \multirow[t]{2}{*}{18} & & $0.83(\mathrm{dd}, 14.3,4.6)$ & $0.76(\mathrm{dd}, 14.9,5.2)$ \\
\hline & & $1.77(\mathrm{~d}, 14.3)$ & $1.85(\mathrm{~d}, 14.9)$ \\
\hline \multirow[t]{2}{*}{19} & $0.78, \mathrm{dd}(14.4,4.1)$ & $2.40(\mathrm{dd}, 18.3,4.0)$ & $2.36(\mathrm{dd}, 16.6,4.0)$ \\
\hline & $1.67, \mathrm{~d}(14.4)$ & $3.38(\mathrm{dd}, 18.3,14.2)$ & $3.25(\mathrm{~d}, 16.6)$ \\
\hline \multirow[t]{2}{*}{20} & $2.35, \mathrm{~m}$ & & \\
\hline & $2.67, \mathrm{~m}$ & & \\
\hline 22 & & $6.97(s)$ & \\
\hline 23 & $6.94, \mathrm{~s}$ & & \\
\hline 24 & & & $6.21(\mathrm{~s})$ \\
\hline 25 & & $7.15(\mathrm{~s})$ & \\
\hline 26 & $7.12, \mathrm{~s}$ & & $2.13(\mathrm{~s})$ \\
\hline 27 & & $2.13(\mathrm{~s})$ & $1.07(\mathrm{~s})$ \\
\hline 28 & $2.36, \mathrm{~s}$ & $1.07(\mathrm{~s})$ & $1.03(\mathrm{~s})$ \\
\hline 29 & $1.16, \mathrm{~s}$ & $1.03(\mathrm{~s})$ & $1.12(\mathrm{~s})$ \\
\hline 30 & $1.07, \mathrm{~s}$ & $1.08(\mathrm{~s})$ & $1.37(\mathrm{~s})$ \\
\hline 31 & $1.11, \mathrm{~s}$ & $1.38(\mathrm{~s})$ & $2.08(\mathrm{~s})$ \\
\hline 32 & $1.31, \mathrm{~s}$ & $2.41(\mathrm{~s})$ & \\
\hline 33 & $2.41, \mathrm{~s}$ & & \\
\hline
\end{tabular}

Compound $5(10.75 \mathrm{mg})$ was obtained as a white amorphous powder. Its formula was deduced via HRESIMS as $\mathrm{C}_{32} \mathrm{H}_{40} \mathrm{O}_{6}$, which was less than that reported for 3 by a $\mathrm{CO}$ group (Figure S3,). The NMR data of $\mathbf{5}$ also indicated similarity to 3 (Tables S1, 3, and 4 and Figures S25-S27). Key differences were the splitting and the upfield shift of the aromatic resonances, for example, $\delta_{\mathrm{H}} 6.16$ and $6.33, \mathrm{~d}, J=1.7$ $\mathrm{Hz}$, for $\mathrm{H}-2$ and $\mathrm{H}-6$, respectively, in 5 vs $\delta_{\mathrm{H}} 6.90$ and 7.13, for $\mathrm{H}-3$ and $\mathrm{H}-7$, respectively in 3 , indicating meta-coupled aromatic protons in $\mathbf{5}$. Moreover, the aromatic methyl singlet $\mathrm{H}_{3}-27$ in 5 was shielded by $0.22 \mathrm{ppm}$ relative to its chemical shift in 3 . In addition, the ${ }^{13} \mathrm{C}$ NMR data of 3 showed two
Table 4. ${ }^{13} \mathrm{C}$ NMR Data for $4\left(100 \mathrm{MHz} \mathrm{CDCl}_{3}\right), 5$ (125 $\left.\mathrm{MHz}, \mathrm{CDCl}_{3}\right)$, and $6\left(125 \mathrm{MHz}, \mathrm{MeOH}-d_{4}\right)$

\begin{tabular}{|c|c|c|c|}
\hline \multirow[b]{2}{*}{ position } & \multicolumn{3}{|c|}{$\delta_{\mathrm{C}}$, type } \\
\hline & 4 & 5 & 6 \\
\hline 1 & 173.4, C & 155.2, C & $155.8, \mathrm{C}$ \\
\hline 2 & 162.6, C & 101.7, CH & $102.7, \mathrm{CH}$ \\
\hline 3 & 113.2, $\mathrm{CH}$ & 153.7, C & $155.8, \mathrm{C}$ \\
\hline 4 & $160.8, \mathrm{C}$ & $110.9, \mathrm{C}$ & 111.5, C \\
\hline 5 & 118.7, C & 139.7, C & 140.0, C \\
\hline 6 & 151.6, C & $110.3, \mathrm{CH}$ & $111.2, \mathrm{CH}$ \\
\hline 7 & $125.3, \mathrm{CH}$ & $29.8, \mathrm{CH}_{2}$ & $30.7, \mathrm{CH}_{2}$ \\
\hline 8 & $34.0, \mathrm{CH}_{2}$ & $32.4, \mathrm{CH}$ & $33.8, \mathrm{CH}$ \\
\hline 9 & 31.6, CH & $80.6, \mathrm{C}$ & $81.7, \mathrm{C}$ \\
\hline 10 & $80.0, \mathrm{C}$ & 71.1, CH & 72.3, CH \\
\hline 11 & $31.5, \mathrm{CH}_{2}$ & $30.4, \mathrm{CH}_{2}$ & $32.5, \mathrm{CH}_{2}$ \\
\hline 12 & 24.5, $\mathrm{CH}_{2}$ & 41.6, $\mathrm{CH}$ & 44.1, CH \\
\hline 13 & $40.9, \mathrm{CH}$ & 81.1, C & 81.0, C \\
\hline 14 & $80.2, \mathrm{C}$ & $46.5, \mathrm{CH}_{2}$ & 47.6, $\mathrm{CH}_{2}$ \\
\hline 15 & 45.4, $\mathrm{CH}_{2}$ & $125.3, \mathrm{CH}$ & 127.1, CH \\
\hline 16 & $124.5, \mathrm{CH}$ & 144.7, CH & 145.2, $\mathrm{CH}$ \\
\hline 17 & $144.0, \mathrm{CH}$ & $35.1, \mathrm{C}$ & $35.8, \mathrm{C}$ \\
\hline 18 & $35.3, \mathrm{C}$ & 46.4, $\mathrm{CH}_{2}$ & 47.6, $\mathrm{CH}_{2}$ \\
\hline 19 & $47, \mathrm{CH}_{2}$ & 33.2, $\mathrm{CH}_{2}$ & $30.6, \mathrm{CH}_{2}$ \\
\hline 20 & $31.4, \mathrm{CH}_{2}$ & 123.4, C & 115.6, C \\
\hline 21 & 121.0, C & 161.0, C & 143.0,C \\
\hline 22 & $160.6, \mathrm{C}$ & 114.1, CH & 132.6, C \\
\hline 23 & $113.4, \mathrm{CH}$ & 163.3, C & $143.8, \mathrm{C}$ \\
\hline 24 & 163.1, C & 172.1, C & $109.9, \mathrm{CH}$ \\
\hline 25 & 172.9, C & $124.8, \mathrm{CH}$ & 127.3, C \\
\hline 26 & $124.8, \mathrm{CH}$ & 151.1, C & 19.7, $\mathrm{CH}_{3}$ \\
\hline 27 & $150.4, \mathrm{C}$ & 19.6, $\mathrm{CH}_{3}$ & 16.1, $\mathrm{CH}_{3}$ \\
\hline 28 & 27.6, $\mathrm{CH}_{3}$ & $15.8, \mathrm{CH}_{3}$ & $30.4, \mathrm{CH}_{3}$ \\
\hline 29 & $22.8, \mathrm{CH}_{3}$ & 29.7, $\mathrm{CH}_{3}$ & 27.9, $\mathrm{CH}_{3}$ \\
\hline 30 & 29.5, $\mathrm{CH}_{3}$ & 27.3, $\mathrm{CH}_{3}$ & $19.6, \mathrm{CH}_{3}$ \\
\hline 31 & 26.9, $\mathrm{CH}_{3}$ & 19.4, $\mathrm{CH}_{3}$ & 18.9, $\mathrm{CH}_{3}$ \\
\hline 32 & 19.6, $\mathrm{CH}_{3}$ & 27.6, $\mathrm{CH}_{3}$ & \\
\hline 33 & 27.4, $\mathrm{CH}_{3}$ & & \\
\hline
\end{tabular}

diagnostic tropolonic carbonyl signals $\left(\delta_{\mathrm{C}} 173.4\right.$ and 172.7 for $\mathrm{C}-1$ and C-25, respectively), while those of 5 showed only one $\left(\delta_{\mathrm{C}} 172.1\right.$ for C-24), which correlated with the $28 \mathrm{amu}$ difference in HRMS data between these compounds. In total, these data were consistent with the substitution of the tropolone $\mathrm{B}$ in 3 by a benzene in 5 . HMBC correlations from $\mathrm{H}_{2}-7$ to $\mathrm{C}-5, \mathrm{C}-3$, and $\mathrm{C}-9$ supported this substitution (Figure S28). The skeleton of $\mathbf{5}$ was confirmed by COSY, HSQC, and HMBC data (Figures 2 and S26-S28). The relative configuration of $\mathbf{5}$ was confirmed to be the same as 3 by NOESY NMR data (Figures S8 and S29). NOESY correlations from $\mathrm{H}-8$ to $\mathrm{H}_{3}-28$ and $\mathrm{H}-16$, and from $\mathrm{H}-16$ to $\mathrm{H}-12$, confirmed the syn-fusion at C-8/C-9 and the anti-fusion at $\mathrm{C}-12 / \mathrm{C}-13$. The name noreupenifeldin $\mathrm{B}$ was ascribed to 5 , which was found to be different from the previously reported noreupenifeldin. ${ }^{9}$ Essentially, the position of the tropolone and the benzene are opposite between these two. An attempt to assign the absolute configuration of $\mathbf{5}$ using Mosher's esters $\operatorname{method}^{8}$ was unsuccessful, and this finding was consistent with the challenges reported for determining the absolute configuration of ramiferin. ${ }^{10}$

Compound 6 (4.96 $\mathrm{mg}$ ) was obtained as a light brown amorphous powder. Its formula was deduced as $\mathrm{C}_{31} \mathrm{H}_{40} \mathrm{O}_{6}$ by HRESIMS, which was less than that for $\mathbf{5}$ by one carbon, as 
evidenced by a 12 amu difference in the HRMS data (Figure S3). The NMR data of 6 indicated similarity to 5, except for the aromatic region (Tables 3 and 4 and Figures S30-S32). There were several lines of evidence that suggested that 6 did not contain a tropolone, and these included (a) the lack of a signal for a carbonyl group, (b) the presence of one singlet aromatic methine proton (i.e., $\delta_{\mathrm{H}} 6.21$ for $\mathrm{H}-24$ in 6 vs $\delta_{\mathrm{H}} 6.97$ and 7.15 for $\mathrm{H}-22$ and $\mathrm{H}-25$, respectively in 5), (c) the shielding of the aromatic methyl singlet $\mathrm{H}_{3}-31$ in 6 by 0.33 ppm, and (d) a missing carbon resonance. These data suggested that the tropolone in 5 was replaced by a pentasubstituted benzene in 6 . The ${ }^{13} \mathrm{C}$ NMR data of 6 indicated a 1,2,3-trioxygenated aromatic system $\left(\delta_{\mathrm{C}}\right.$ 143.0, 132.6, and 143.8 for C-21, C-22, and C-23, respectively) (Table 4). HMBC correlations from $\mathrm{H}_{3}-31$ to $\mathrm{C}-20$ and C-24, from $\mathrm{H}_{2}-19$ to $\mathrm{C}-25$, and from $\mathrm{H}-24$ to $\mathrm{C}-20$ and $\mathrm{C}-23$ supported this substitution pattern (Figures 2 and S33). The skeleton of 6 was further confirmed by COSY, HSQC, and HMBC data (Figures 2 and S31-33). The relative configuration of $\mathbf{6}$ was the same as that of $\mathbf{3}$ and $\mathbf{5}$ on the basis of NOESY NMR data (Figures S15 and S34). For example, NOESY correlations from $\mathrm{H}-8$ to $\mathrm{H}_{3}-27$ and $\mathrm{H}-16$, from $\mathrm{H}-16$ to $\mathrm{H}-14 \mathrm{a}$, and from $\mathrm{H}-14 \mathrm{a}$ to $\mathrm{H}-12$ confirmed the syn-fusion at C-8/C-9 and the anti-fusion at C-12/C-13. The name 22-hydroxyramiferin was ascribed to 6 , which was found to be different from the previously described ramiferin, a bisphenol analogue of eupenifeldin (3), via a hydroxy at C-22. ${ }^{10}$ As in $\mathbf{5}$, we were unable to assign the absolute configuration of 6 using Mosher's esters method. ${ }^{8}$

Compounds $1-6$ were tested against a panel of cancer cell lines, including MDA-MB-231 (human breast cancer), OVCAR-3, and OVCAR-8 (human ovarian cancers), MSTO$211 \mathrm{H}$ (human mesothelioma), LLC (murine lung cancer), and A549 (human lung cancer) (Table 5). Compound 3 was the most potent with $\mathrm{IC}_{50}$ values of $2830,330,20,80,10$, and $1330 \mathrm{nM}$, respectively, followed by compound 4 .

Table 5. Activities of Compounds 1-6 against Six Tumor Cell Lines

\begin{tabular}{lcccccc} 
& \multicolumn{7}{c}{$\mathrm{IC}_{50}{ }^{a}(\mu \mathrm{M})$} \\
\cline { 2 - 7 } compd & $\begin{array}{c}\text { MDA-MB- } \\
231\end{array}$ & OVCAR- & OVCAR- & MSTO- & & \\
$\mathbf{1}$ & 14.9 & 10.6 & 2.38 & 0.82 & & 1.24 \\
$\mathbf{2}$ & 11.2 & 3.80 & 1.08 & 0.28 & 0.12 & \\
$\mathbf{3}$ & 2.83 & 0.33 & 0.02 & 0.08 & 0.01 & 1.33 \\
$\mathbf{4}$ & 6.02 & 0.43 & 0.07 & 0.13 & 0.27 & \\
$\mathbf{5}$ & 7.06 & 2.41 & 0.46 & 0.44 & 0.29 & \\
$\mathbf{6}$ & 13.5 & 7.76 & 0.89 & 0.72 & & \\
Taxol & 0.72 & 0.08 & 0.06 & 0.02 & 0.01 & 0.004
\end{tabular}

${ }^{a} \mathrm{IC}_{50}$ values were determined as the concentration required to inhibit growth to $50 \%$ of control with a $72 \mathrm{~h}$ incubation.

While cytotoxicity is essential to the anticancer application of these compounds, equally important is a lack of toxicity to healthy tissues. In particular, the clinical failure of numerous agents due to mitochondrial-based cardio- or hepatotoxicity has led to an increasing emphasis on mitochondrial toxicity. ${ }^{11}$ Therefore, compounds 1-3, which represented the greatest structural diversity among these meroterpenoids, were evaluated for mitochondrial toxicity in vitro (Promega Mitochondrial ToxGlo). No toxicity was observed up to the maximum concentration tested $(12.5 \mu \mathrm{M})$.
Six meroterpenoids $(\mathbf{1}-\mathbf{6})$, of which five are new and one possesses a novel dioxa[4.3.3] propellane ring system, were isolated and elucidated from Neosetophoma sp. (strain MSX50044). Cytotoxicity assays revealed compound 3, possessing two tropolone moieties, to be the most potent against a panel of cell lines while not exhibiting toxicity against mitochondria. Additionally, this fungus is a prolific producer of 3 with a yield that exceeds $28 \%$ of the dried organic extract. Such ample material of a potent, structurally complex compound opens the door for further studies to enhance activity and optimize delivery, ${ }^{12}$ particularly given the in vivo activity in the P388 leukemia model noted previously. ${ }^{6}$ Tropolonic sesquiterpenes are a unique subclass of meroterpenoids with a broad range of biological activities, including cytotoxic, ${ }^{3,6,7,10,13,14}$ anthelmintic, ${ }^{9}$ antimalarial, ${ }^{10}$ and antimicrobial. ${ }^{3}$ Others have shown a number of tricyclic propellanes connected by a carbon-carbon single bond that also display a broad range of activities, including antimicrobial and anticancer. ${ }^{15,16}$ These findings highlight the biosynthetic potential of fungi to create novel chemical structures, encourage continued discovery of new agents and activities, and provide motivation to usher natural products to the clinic.

\section{ASSOCIATED CONTENT}

\section{Supporting Information}

The Supporting Information is available free of charge on the ACS Publications website at DOI: 10.1021/acs.orglett.8b03769.

Experimental procedures, UPLC chromatograms of compounds 1-6, 1D and 2D NMR spectra for compounds 1-6, key NOESY correlations of 1, 2 and 4-6, representative preparative HPLC chromatograms for the purification of compounds 1-6, HRESIMS, UV, and IR spectra, and phylograms of the most likely tree (PDF)

\section{Accession Codes}

CCDC 1873628 contains the supplementary crystallographic data for this paper. These data can be obtained free of charge via www.ccdc.cam.ac.uk/data_request/cif, or by emailing data_request@ccdc.cam.ac.uk, or by contacting The Cambridge Crystallographic Data Centre, 12 Union Road, Cambridge CB2 1EZ, UK; fax: +44 1223336033.

\section{AUTHOR INFORMATION}

\section{Corresponding Author}

*E-mail: nicholas_oberlies@uncg.edu. ORCID $\odot$

Huzefa A. Raja: 0000-0002-0824-9463

Mark W. Grinstaff: 0000-0002-5453-3668

Nicholas H. Oberlies: 0000-0002-0354-8464

Notes

The authors declare no competing financial interest.

\section{ACKNOWLEDGMENTS}

This research was supported by National Institutes of Health grants P01 CA125066 (N.H.O., C.L.P.), R01 CA227433 (M.W.G., N.H.O.), and T32 EB006359 (R.C.S.). ${ }^{17}$

\section{REFERENCES}

(1) Matsuda, Y.; Awakawa, T.; Abe, I. Tetrahedron 2013, 69, 8199. 
(2) Matsuda, Y.; Abe, I. Nat. Prod. Rep. 2016, 33, 26.

(3) Overy, D. P.; Berrue, F.; Correa, H.; Hanif, N.; Hay, K.; Lanteigne, M.; Mquilian, K.; Duffy, S.; Boland, P.; Jagannathan, R.; Carr, G. S.; Vansteeland, M.; Kerr, R. G. Mycology 2014, 5, 130.

(4) Hoffmann, T.; Krug, D.; Bozkurt, N.; Duddela, S.; Jansen, R.; Garcia, R.; Gerth, K.; Steinmetz, H.; Müller, R. Nat. Commun. 2018, 9, 803.

(5) El-Elimat, T.; Figueroa, M.; Ehrmann, B. M.; Cech, N. B.; Pearce, C. J.; Oberlies, N. H. J. Nat. Prod. 2013, 76, 1709.

(6) Mayerl, F.; Gao, Q.; Huang, S.; Klohr, S. E.; Matson, J. A.; Gustavson, D. R.; Pirnik, D. M.; Berry, R. L.; Fairchild, C.; Rose, W. C. J. Antibiot. 1993, 46, 1082.

(7) Zhang, J.; Liu, L.; Wang, B.; Zhang, Y.; Wang, L.; Liu, X.; Che, Y. J. Nat. Prod. 2015, 78, 3058.

(8) Hoye, T. R.; Jeffrey, C. S.; Shao, F. Nat. Protoc. 2007, 2, 2451.

(9) Ayers, S.; Zink, D. L.; Powell, J. S.; Brown, C. M.; Grund, A.; Bills, G. F.; Platas, G.; Thompson, D.; Singh, S. B. J. Nat. Prod. 2008, $71,457$.

(10) Bunyapaiboonsri, T.; Veeranondha, S.; Boonruangprapa, T.; Somrithipol, S. Phytochem. Lett. 2008, 1, 204.

(11) Vorrink, S. U.; Zhou, Y.; Ingelman-Sundberg, M.; Lauschke, V. M. Toxicol. Sci. 2018, 163, 655.

(12) Colby, A. H.; Oberlies, N. H.; Pearce, C. J.; Herrera, V. L. M.; Colson, Y. L.; Grinstaff, M. W. Wiley Interdiscip. Rev.: Nanomed. Nanobiotechnol. 2017, 9, e1451.

(13) Hsiao, C.-J.; Hsiao, S.-H.; Chen, W.-L.; Guh, J.-H.; Hsiao, G.; Chan, Y.-J.; Lee, T.-H.; Chung, C.-L. Chem.-Biol. Interact. 2012, 197, 23.

(14) Kaneko, M.; Matsuda, D.; Ohtawa, M.; Fukuda, T.; Nagamitsu, T.; Yamori, T.; Tomoda, H. Biol. Pharm. Bull. 2012, 35, 18.

(15) Dilmaç, A. M.; Spuling, E.; de Meijere, A.; Bräse, S. Angew. Chem., Int. Ed. 2017, 56, 5684.

(16) Pihko, A. J.; Koskinen, A. M. P. Tetrahedron 2005, 61, 8769.

(17) Grinstaff, M. W.; Kaplan, H. M.; Kohn, J. ACS Biomater. Sci. Eng. 2018, 4, 3919. 